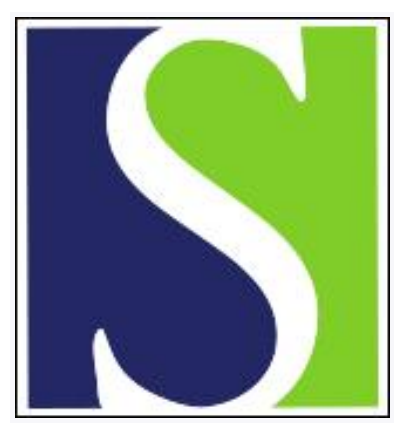

Scand J Work Environ Health 1983;9(4):341-345

https://doi.org/10.5271/sjweh.2403

Issue date: Aug 1983

Correlates of mental health in nuclear and coal-fired power plant workers.

by Parkinson DK, Bromet EJ

This article in PubMed: www.ncbi.nlm.nih.gov/pubmed/6635612

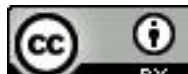




\title{
Correlates of mental health in nuclear and coal-fired power plant workers
}

\author{
by David K Parkinson, BM, MS,' Evelyn J Bromet, PhD²
}

\begin{abstract}
PARKINSON DK, BROMET EJ. Correlates of mental health in nuclear and coal-fired power plant workers. Scand $j$ work environ health 9 (1983) $341-345$. The mental health of 104 nuclear workers at the Three Mile Island plant was compared with that of 122 workers from another nuclear plant and 151 workers from two coal-fired generating plants. The coal-fired plant workers were somewhat more symptomatic than the nuclear plant workers. Assessments of work environments showed that the coal-fired plant workers perceived less stress but more problems with workplace exposures than the nuclear plant workers. Negative perceptions of work and marital stress were both strongly and independently related to mental distress. Overall, the results suggest that the Three Mile Island accident did not engender long-term psychological difficulties in workers evaluated 2.5 years after the accident.
\end{abstract}

Key terms: job satisfaction, occupational exposure, work stress.

Prior to the accident at the Three Mile Island nuclear plant in March 1979 the mental health of nuclear power plant workers had not been studied from an epidemiologic perspective. The accident at Three Mile Island provided an opportunity to examine the workers' mental health in relation to the accident. Two studies were subsequently conducted. Kasl and his colleagues (5) carried out a telephone survey in August-September 1979 under the auspices of the Behavioral Effects Task Group of the President's Commission on the Accident at Three Mile Island. Supervisory and nonsupervisory workers at Three Mile Island were compared with nuclear workers at a similar plant 40 miles away. With respect to mental health, nonsupervisory Three Mile Island workers retrospectively reported more hostility, psychophysiological symptoms, and demoralization than the referents at the time of the accident. Significant, albeit smaller, differences were found in symptoms at the time of the interview. (six months

1 Department of Medicine, University of Pittsburgh, Pennsylvania, United States.

2 Department of Psychiatry, University of Pittsburgh, Pennsylvania, United States.

Reprint requests to: Dr EJ Bromet, Department of Psychiatry, 3811 O'Hara St, Pittsburgh, PA 15213 , USA. after the accident). Significant correlations between job tension and sympomatology were also found.

In our own work, sponsored by the National Institute of Mental Health, face-toface interviews assessing diagnostic and subclinical levels of psychiatric disorder were conducted twice during the year after the accident, in January and in April of 1980 (1). Unionized workers at the Three Mile Island plant were compared with members of the same union at the Beaver ValleyShippingport nuclear plant in western Pennsylvania, approximately 250 miles away. Minor differences in rates of clinical psychiatric disorder were found, although the current symptom levels [based on scores from the Symptom Checklist-90 (2)] of the two groups of workers were identical at each interview. Thus the symptom differences which Kasl et al (5) noted to have decreased in magnitude over a six-month interval seemed to have disappeared ten months after the accident.

The problems at the Three Mile Island plant have continued. The utility itself has become concerned about the pressures to which the workers and their families have been exposed as a result of the accident and contracted with a counseling service to provide free psychotherapy to 
workers and their families. One question addressed in this paper is whether Three Mile Island workers have indeed been experiencing psychological strain that can be attributed to working at that plant. Data used in this analysis were collected 2.5 years after the accident. The second question raised is whether Three Mile Island workers experienced more stress at work and at home than other power plant workers. Union employees at the Beaver Valley-Shippingport plant and at two coal-fired generating plants in western Pennsylvania served as the reference groups. Finally, the relationship between symptomatology and a variety of psychosocial factors is examined in relation to the Three Mile Island workers and compared to the patterns observed for workers in the other power plants. Perceptions of stress in the work and home environments are the central focus of this analysis.

\section{Subjects and methods}

\section{Subjects}

The analyses presented in this paper were based on information from 377 male union workers interviewed in the fall of 1981. Included were 104 Three-Mile Island workers, 122 Beaver Valley-Shippingport workers, and 151 coal-fired generation plant workers. All the employees on the union lists (the entire nonmanagerial work force, excluding the contractor personnel) were asked to participate. The refusal rate for the three groups averaged $20 \%$. The mean age of the workers was 36 years at the nuclear plants and 37 years at the coalfired sites. Relatively more Beaver ValleyShippingport workers had some education beyond high school $65 \%$ vs $50 \%$ of the Three Mile Island workers and $46 \%$ of the coal-fired plant workers). Family income levels were also higher for the Beaver Valley-Shippingport workers, $60 \%$ reporting annual incomes of USD $\geq 30,000$ compared to $44 \%$ of the Three Mile Island and $23 \%$ of the coal-fired plant workers. Most workers in each plant were married $(92 \%$ at Three Mile Island, $87 \%$ at the Beaver Valley-Shippingport plants and $80 \%$ at the coal-fired plants). Since one focus of this paper is on mari- tal stress, some of the analyses presented have been based on the married workers only.

\section{Methods}

Face-to-face interviews were conducted in the home and lasted approximately 1.5 h. The subjects were randomly assigned to interviewers, who were mental health professionals working with the project on a part-time basis. They had at least a master's degree in a psychiatric field and an average of eight years of clinical experience.

Mental health. Current symptom levels were determined from responses to the Symptom Checklist-90 (2), in which symptoms occurring during the past two weeks are rated on a five-point distress scale. The average distress level for the 90 items, ie, the Global Severity Index, is presented in our report.

Work environment. Three work environment indicators were selected: work stress, job satisfaction and occupational exposure. Work stress was assessed by responses to 12 items developed and validated at the University of Michigan and widely used in studies of occupational stress (3). These items are rated on a fivepoint scale and reflect pressures about job responsibilities, quality concern, conflicts about satisfying other people's expectations, feelings that the job interferes with nonwork life, and feelings of being trapped by the job. Scores can range from 0 (no stress) to 48 (maximum stress). Job satisfaction was determined from a five-item scale concerning whether the worker was satisfied and happy with his job (and the level of satisfaction and happiness), whether he would make the same decision now to take the job and/or recommend it to a good friend, and whether the job measures up to his prior expectations. Scores can range from 0 (high satisfaction) to 20 (low satisfaction). Occupational exposure was assessed by having workers rate the extent to which 11 sets of exposures (eg, toxic chemicals, air pollution, dangerous storage of equipment, noise) were problematic; the ratings were made on a five-point scale from no exposure to exposure presenting a great 
problem. The measure used in this report was the average problem rating across the 11 sets of exposures (range $=0-4$ ).

Home environment. The marital relationship was the focus of the home environment analysis. Marital conflict and marital satisfaction subscales were derived from a questionnaire which incorporated items from the marital adjustment scales of Spanier (8) and Pearlin \& Schooler (6). The marital conflict subscale contained five items that dealt with experiencing marital problems, seeking marital advice from relatives or friends, considering divorce or separation, leaving home because of a fight, seeking professional counseling for the marriage [range: 5 (no conflict) 25 (high conflict)]. Marital satisfaction included reports about affectionate behavior and positive evaluations of the marriage [range: 6 (low satisfaction) - 30 (high satisfaction)].

With the one-way analysis of variance the delineated variables were compared for differences among the plants. Multiple regression analyses were computed to evaluate the amount of variance in current symptom levels accounted for by the work and marital environment measures. In these analyses, other independent variables shown to affect current symptomatology in psychiatric epidemiologic research were also entered. These variables included number of stressful life events occurring during the year prior to the interview, perception of friendship support, age, education, frequency of alco- hol consumption in the year prior to the interview (11-point scale from never to three or more times a day), and current smoking habits (5-point scale from nonsmoker to smoking more than one pack per day).

\section{Results}

Table 1 shows the mean difference in current symptom levels (Global Severity Index) among the groups. The Three Mile Island and Beaver Valley-Shippingport workers had similar distress scores, but the workers from the coal-fired plants were somewhat more symptomatic than the nuclear cohorts. When a cut-off was used of one standard deviation above the mean of the normative male sample from Derogatis' validation study, $25 \%$ of the coal-fired plant workers had scores reflecting high distress in comparison to $21 \%$ of the Three Mile Island and Beaver Valley-Shippingport workers.

Table 1 also gives the results for the work and marital stress perception. There were no significant differences among the plants with respect to perceptions of the marriage. Moreover the mean scores were at the positive end of the scales. With respect to the work enwironment, the workers from the coal-fired plants reported less work stress and more problems with exposure than the nuclear workers.

Table 2 presents the correlations between the Global Severity Index and work and marital stress scales. For the Three Mile Island workers work stress correlated the strongest with the Global Severity

Table 1. Differences in current symptoms and work and marital stress among the Three Mile Island (TMI), Beaver Valley-Shippingport (BV-S), and coal-fired plant (CF) workers - One-way analysis of variance.

\begin{tabular}{|c|c|c|c|c|c|c|c|c|c|c|}
\hline \multirow{2}{*}{ Variable } & \multicolumn{3}{|c|}{ TMI } & \multicolumn{3}{|c|}{ BV-S } & \multicolumn{3}{|c|}{ CF } & \multirow{2}{*}{ p-Value } \\
\hline & Mean & SD & $\mathbf{N}$ & Mean & SD & $\mathbf{N}$ & Mean & $\mathrm{SD}$ & $\mathbf{N}$ & \\
\hline $\begin{array}{l}\text { Global Severity } \\
\text { Index }\end{array}$ & 0.27 & 0.29 & 104 & 0.28 & 0.21 & 122 & 0.34 & 0.30 & 151 & 0.10 \\
\hline Work stress & 18.39 & 7.68 & 104 & 19.63 & 6.98 & 122 & 17.42 & 7.40 & 151 & 0.05 \\
\hline $\begin{array}{l}\text { Job satis- } \\
\text { faction } \\
\text { Occupational }\end{array}$ & 6.96 & 2.50 & 104 & 6.70 & 2.43 & 122 & 6.36 & 2.58 & 151 & NS \\
\hline exposure & 1.24 & 0.78 & 104 & 1.59 & 0.79 & 122 & 2.40 & 0.68 & 151 & 0.001 \\
\hline $\begin{array}{l}\text { Marital } \\
\text { conflict }\end{array}$ & 7.59 & 2.43 & 96 & 7.34 & 2.63 & 106 & 7.68 & 2.80 & 121 & NS \\
\hline $\begin{array}{l}\text { Marital } \\
\text { satisfaction }\end{array}$ & 24.19 & 4.05 & 94 & 23.85 & 4.19 & 105 & 23.51 & 4.19 & 121 & NS \\
\hline
\end{tabular}


Index. Job satisfaction and exposure were unrelated to the Index. Higher symptom levels were also associated with greater conflict and less satisfaction in the marriage. In the Beaver Valley-Shippingport and coal-fired plant groups, all of the work and marital environment scales correlated with the Global Severity Index at significant levels. The coalfired plant workers showed a more striking relationship between occupational exposure and mental health than the nuclear workers.

Table 3 presents the results of stepwise regression analyses which consider the effect on symptom levels of the occupational and home environments, along with other independent variables associated with mental health in epidemiologic research. Among the Three Mile Island workers, $40 \%$ of the variance was explained by the array of independent variables entered. Work stress, job satisfaction, marital satisfaction, friendship support, and

Table 2. Relationships between current symptoms and work and marital stress by site - Pearson correlation coeffecients. (TMI = Three Mile Island, $\mathrm{BV}-\mathrm{S}=$ Beaver Valley-Shippingport, $\mathrm{CF}=$ coalfired plants)

\begin{tabular}{|c|c|c|c|}
\hline \multirow{2}{*}{ Variable } & \multicolumn{3}{|c|}{ Global Severity Index } \\
\hline & TMI & BV-S & CF \\
\hline $\begin{array}{l}\text { Work stress } \\
\text { Job satisfaction } \\
\text { Occupational }\end{array}$ & $\begin{array}{l}0.48^{\star \star \star} \\
-0.14\end{array}$ & $\begin{aligned} & 0.29^{* * *} \\
- & 0.20^{\star}\end{aligned}$ & $\begin{array}{r}0.38^{\star \star \star} \\
-0.26^{\star \star \star}\end{array}$ \\
\hline $\begin{array}{l}\text { exposure } \\
\text { Marital conflict } \\
\text { Marital satisfaction }\end{array}$ & $\begin{array}{l}0.13 \\
0.27^{\star \star} \\
-0.32^{\star \star \star}\end{array}$ & $\begin{array}{r}0.17^{\star} \\
0.37^{\star \star \star} \\
-0.31^{\star \star \star}\end{array}$ & $\begin{array}{r}0.28^{\star \star \star} \\
0.44^{\star \star *} \\
-0.41^{\star \star \star}\end{array}$ \\
\hline
\end{tabular}

life events contributed the most strongly to the variance. By contrast, the same array of variables explained considerably less of the variance among the Beaver Valley-Shippingport workers (27 \%), work stress, marital conflict, and friendship support accounting for almost all of the variance. Among the coal-fired plant workers, $39 \%$ of the variance was explained chiefly by marital conflict and satisfaction, work stress and exposure, life events, and education. Thus work and marital stress made significant independent contributions to the workers' mental health in all three groups.

\section{Discussion}

The results indicated that the coal-fired plant workers reported somewhat greater psychological impairment than the workers in nuclear power facilities. This pattern was not accompanied by differences in psychosocial stress at home or at work. In fact the coal-fired plant workers reported lower levels of job stress than the nuclear workers. The major area in which the workers differed was their exposure to potentially harmful agents in the workplace, coal-fired plant workers reporting significantly more problems with exposures than either of the nuclear groups. Although the majority of exposures studied in the present investigation have no known neurotoxic effects (ie, dust, smoke, fibers, equipment stored dangerously, etc), the correlation between exposure and the Global Severity Index was 0.28 for the coal-fired plant workers,

Table 3. Regression of current symptoms on stress and other variables affecting mental health. (TMI = Three Mile Island workers, BV-S = Beaver Valley-Shippingport workers, CF = coal-fired plant workers)

\begin{tabular}{|c|c|c|c|c|c|c|}
\hline \multirow[b]{2}{*}{ Variable } & \multicolumn{2}{|c|}{ TMI $(\mathbf{N}=93)$} & \multicolumn{2}{|c|}{$B V-S(N=105)$} & \multicolumn{2}{|c|}{$\mathrm{CF}(\mathrm{N}=117)$} \\
\hline & Beta & $\begin{array}{c}\text { Cumula- } \\
\text { tive } \mathrm{R}^{2}\end{array}$ & Beta & $\begin{array}{c}\text { Cumula- } \\
\text { tive } \mathrm{R}^{2}\end{array}$ & Beta & $\begin{array}{c}\text { Cumulz- } \\
\text { tive } R^{2}\end{array}$ \\
\hline $\begin{array}{l}\text { Work stress } \\
\text { Job satisfaction } \\
\text { Occupational exposure } \\
\text { Marital conflict } \\
\text { Marital satisfaction } \\
\text { Friendship support } \\
\text { Life events } \\
\text { Age } \\
\text { Education } \\
\text { Drinking frequency } \\
\text { Smoking habits }\end{array}$ & $\begin{array}{l}0.52^{\star \star \star} \\
0.16^{\star \star} \\
-0.07 \\
- \\
-0.26^{\star \star \star} \\
0.23^{\star \star \star} \\
0.16^{\star \star} \\
0.10 \\
0.07 \\
0.03 \\
-0.05\end{array}$ & $\begin{array}{l}0.23 \\
0.35 \\
0.38 \\
- \\
0.28 \\
0.33 \\
0.36 \\
0.39 \\
0.40 \\
0.40 \\
0.38\end{array}$ & $\begin{array}{c}0.23^{* * *} \\
- \\
0.13 \\
0.19^{\star} \\
-0.13 \\
-0.15^{*} \\
-0.02 \\
0.02 \\
0.08 \\
- \\
-0.02\end{array}$ & $\begin{array}{l}0.21 \\
-\overline{0} \\
0.26 \\
0.14 \\
0.26 \\
0.24 \\
0.27 \\
0.27 \\
0.27 \\
\overline{0.27}\end{array}$ & $\begin{array}{l}0.24^{\star \star \star \star} \\
-0.10 \\
0.24^{\star \star \star *} \\
0.21^{\star \star \star} \\
-0.19^{\star \star \star} \\
-0.05 \\
0.14^{\star \star} \\
0.05 \\
-0.12^{\star} \\
-0.02 \\
-0.04\end{array}$ & $\begin{array}{l}0.32 \\
0.39 \\
0.26 \\
0.18 \\
0.30 \\
0.39 \\
0.37 \\
0.39 \\
0.36 \\
0.39 \\
0.39\end{array}$ \\
\hline
\end{tabular}

* $p<0.05,{ }^{* *} p<0.01,{ }^{\star \star \star} p<0.001$. 
compared to 0.13 and 0.17 for the Three Mile Island and Beaver Valley-Shippingport workers, respectively. Thus workplace exposure problems (perceived or real) may partially explain the elevated symptom levels found among the coalfired plant workers.

The relationship between work stress and mental health has been well documented for white-collar workers (4). Although work stress and job satisfaction correlated with each other $(-0.38$ for Three Mile Island, -0.54 for Beaver ValleyShippingport, and -0.39 for coal-fired plant workers), they were differentially related to mental health, particularly among the Three Mile Island workers. Thus it was important to include both variables in the regression analyses.

One explanation for the similarity of the correlation coefficients of work and marital stress in relation to mental health is consistency in response style in that the workers tended to perceive the various domains of their lives consistently as more or less stressful. The fact that both the work and marital variables entered the regression equation indicates, however, that they were not so interdependent as to cancel one another out. It also suggests the need to reevaluate inferences about the work stress-mental health relationship since perceptions of the work environment may reflect more about the individual worker than the setting in which he is employed. In this vein, it is instructive to note that objective measures of work stress have not been found to correlate with psychological symptomatology $(4,7)$.

Overall our findings suggest that the impact of the Three Mile Island accident on workers at the plant was unremarkable 2.5 years after the accident. We have consistently failed to find that Three Mile Island workers are more symptomatic than other power plant employees. Although the accident may have precipitated short-term mental health effects in
1979, there do not appear to be any residual effects beyond that period.

\section{Acknowledgments}

This research was funded in part by National Institute of Mental Health grant MH35425.

We wish to thank JR Bush and Ms M Connell for their help with the data analysis and members of the International Brotherhood of Electrical Workers and Utility Workers of America for their help in implementing the study.

\section{References}

1. Bromet EJ, Parkinson DK, Schulberg HC, Dunn LO, Gondek PC. Mental health of residents near the Three Mile Island reactor: A comparative study of selected groups. $J$ prev psychiatr 1 (1982) 225-275.

2. Derogatis LR. The SCL-90 Manual I: Scoring, administration and procedures for the SCL-90. Johns Hopkins University School of Medicine Clinical Psychometrics Unit, Baltimore, MD 1977.

3. House JS, McMichael AJ, Wells JA, Kaplan $\mathrm{BH}$, Landerman LR. Occupational stress and health among factory workers. J health soc behavior 20 (1979) 139-160.

4. Kasl SV. Epidemiological contributions to the study of work stress. In: Cooper CL, Payne R, ed. Stress at work. John Wiley \& Sons, New York, NY 1978, pp 3-48.

5. Kasl SV, Chisholm RF, Eskenazi B. The impact of the accident at Three Mile Island on the behavior and well-being of nuclear workers. Am j publ health 71 (1981) 472-495.

6. Pearlin L, Schooler N. The structure of coping. J health soc behavior 19 (1978) 2-21.

7. Rose R, Hurst M, Herd J. Cardiovascular and endocrine responses to work and the risk of psychiatric symptomatology among air traffic controllers. In: Barrett $J$, ed. Stress and mental disorder. Raven Press, New York, NY 1979, pp 237-250.

8. Spanier G. Measuring dyadic adjustment. $\mathrm{J}$ marriage fam 2 (1976) 15-28.

Received for publication: 29 March 1983 